Loma Linda University

TheScholarsRepository@LLU: Digital Archive of Research, Scholarship \& Creative Works

Loma Linda University Electronic Theses, Dissertations \& Projects

6-1980

\title{
Changes of the Marginal Periodontium as a Result of Labial Tooth Movement in Monkeys
}

Gregory G. Steiner

J. K. Pearson

J. Ainamo

Follow this and additional works at: https://scholarsrepository.llu.edu/etd

Part of the Periodontics and Periodontology Commons

\section{Recommended Citation}

Steiner, Gregory G.; Pearson, J. K.; and Ainamo, J., "Changes of the Marginal Periodontium as a Result of Labial Tooth Movement in Monkeys" (1980). Loma Linda University Electronic Theses, Dissertations \& Projects. 1232.

https://scholarsrepository.llu.edu/etd/1232

This Dissertation is brought to you for free and open access by TheScholarsRepository@LLU: Digital Archive of Research, Scholarship \& Creative Works. It has been accepted for inclusion in Loma Linda University Electronic Theses, Dissertations \& Projects by an authorized administrator of TheScholarsRepository@LLU: Digital Archive of Research, Scholarship \& Creative Works. For more information, please contact scholarsrepository@llu.edu. 


\author{
Abstract \\ CHANGES OF THE MARGINAL PERIODONTIUM AS A \\ RESULT OF LABIAL TOOTH MOVEMENT IN MONKEYS \\ by \\ Gregory G. Steiner, J. K. Pearson, \\ and J. Ainamo
}

Orthodontic tooth movement was performed on five monkeys (Macaca nemistrina). Oral health was established and exploratory surgery was performed to assess the level of the connective tissue attachment and marginal bone. Measurements of the gingival margin and mucogingival junction were taken and orthodontic forces were applied. The central incisors were moved labially a mean distance of $3.05 \mathrm{~mm}$. Post therapy measurements were performed to assess the change which occurred as a result of tooth movement. Significant recession of the gingival margin, connective tissue level and marginal bone was found when compared to an amalgam marker located on the facial surface of the displaced central incisors. The distance from the amalgam marker to the mucogingival junction increased enough to compensate for the decreasing effect of the recession on the width of the keratinized gingiva. 
LOMA LINDA UNIVERSITY

Graduate School

\author{
CHANGES OF THE MARGINAL PERIODONTIUM AS A \\ RESULT OF LABIAL TOOTH MOVEMENT IN MONKEYS \\ by \\ Gregory G. Steiner, J. K. Pearson, \\ and J. Ainamo
}

\begin{abstract}
A Manuscript Submitted by Gregory G. Steiner in Partial Fulfillment of the Requirements for the Degree Master of Science in Periodontology
\end{abstract}


Each person whose signature appears below certifies that this manuscript in his opinion is adequate, in scope and quality, in lieu of a thesis for the degree Master of Science.
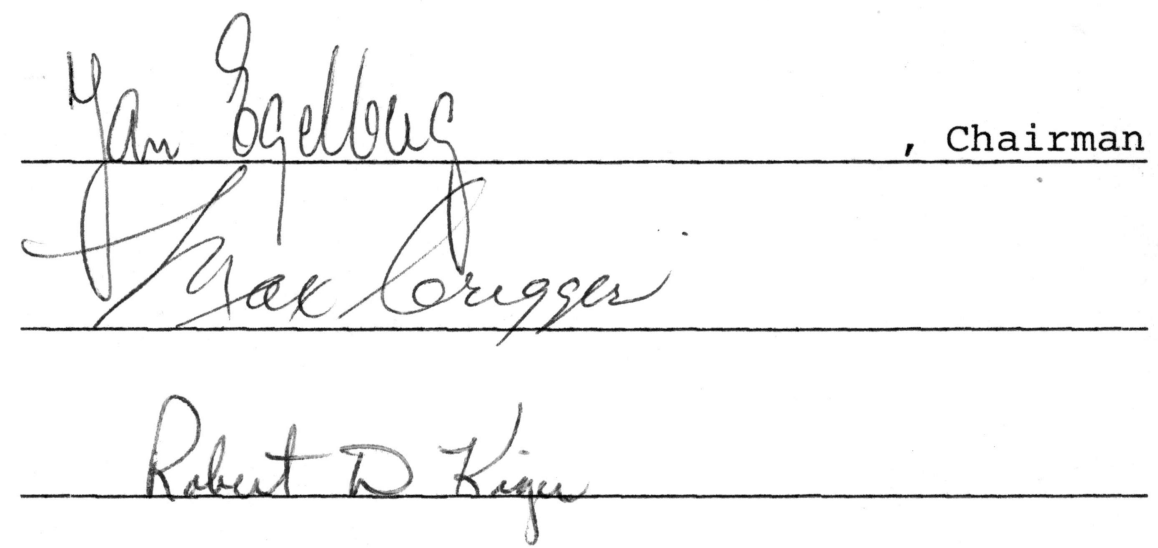


\section{ACKNOWLEDGEMENTS}

Appreciation is extended to the Department of Animal Care and the Department of Bio-Statistics for their assistance. Appreciation is also extended to the Department of Periodontics, namely, Jan Egelberg, L.D.S., Max Crigger, D.D.S. and Jukka Ainamo, D.D.S. for their indispensable guidance and stimulation, and the Graphics Department for their assistance with the construction of the graphic illustrations, and to Julie Cranfill for her secretarial assistance. 


\section{INTRODUCTION}

Tooth position has been suggested to be an important factor in gingival recession. In an attempt to determine the prevalence of and etiologic factors associated with gingival recession Parfitt and Mjor $^{1}$ examined 668 school children 9-12 years of age. In this group $8 \%$ of the children were found to have between two and five millimeters of gingival recession associated with the mandibular incisors. Of the factors considered, tooth-arch discrepancies were found to be most commonly associated with the observed recession. In fact, the authors state that $80 \%$ of the affected teeth had a tootharch discrepancy.

In a similar study Trott and Love ${ }^{2}$ studied a group of 766 high school students 14-19 years of age. The labial surfaces of the mandibular anteriors were examined for the incidence of recession, and factors most commonly associated with the recession observed. $1.8 \%$ of the teeth examined were reported to have recession of greater than three millimeters. The factor most commonly associated with recession was tooth malposition.

Gorman $^{3}$ examined 164 subjects from 16-86 years of age for recession. Recession was considered to be any amount of root exposure. $61 \%$ of the teeth in pronounced labioversion 
(32 out of 52) were found to have some degree of recession and $15 \%$ of the teeth in pronounced linguoversion (4 out of 26) had gingival recession. Of the factors examined, Gorman ${ }^{3}$ cites malposition of the teeth as the factor most frequently associated with recession.

Pearson ${ }^{4}$ conducted a study on 27 untreated and 45 orthodontically treated cases. The untreated cases were considered normal and the treated cases were selected because they exhibited the most severe amount of gingival recession out of a total of 600 treated cases. The untreated cases were examined for amount of recession initially and two years later. The treated group was examined for amount of recession before and after orthodontic therapy. The average gingival height of the two mandibular centrals served as the basis for comparison between treated and untreated groups. The positions of the teeth were assessed by cephalometic tracings. The untreated cases showed an average of $0.04 \mathrm{~mm}$ gingival recession and the treated group exhibited $1.1 \mathrm{~mm}$ recession. However, the author stated that no correlation could be found between the amount of labial or lingual tooth movement and the degree of recession.

Batenhorst et al. ${ }^{5}$ examined the effects of orthodontic movement in two rhesus monkeys. Bands were placed on the mandibular anterior teeth and forces were applied for a 
period of 54 to 64 days in order to tip one lower central and one lower lateral incisor facially in each monkey. The tipped teeth were to serve as experimental and contralateral teeth as controls. A maintenance period of 240 days was allowed for retention. The resulting tooth movement was found to be in a facial and coronal direction. Apical displacement of the gingival margin in relation to the experimental teeth was found to average 3.2 millimeters. On the controls, apical displacement was minimal. The amount of attached gingiva was found to increase on an average 1.6 millimeters for the experimental teeth, with minimal changes for the controls.

Recently Dorfman ${ }^{6}$ published a study in which photographs of orthodontically treated cases were examined for areas of initial minimal keratinized gingiva $(\leq 2 \mathrm{~mm})$ or marked visible changes in the width of keratinized gingiva which occurred during treatment. The initial and final cephalograms from this group of selected cases were also examined for changes in tooth position in order to determine if there was any correlation between mandibular incisor tooth movement and changes seen in keratinized gingiva during orthodontic therapy. The results indicate that patients which had a decrease in keratinized gingiva had no consistent buccal or lingual tooth movement. However, in patient exhibiting an 
increase in keratinized gingiva there was a significant amount of lingual tooth movement.

Thus, the studies by Parfitt and Mjor ${ }^{1}$, Trott and Love ${ }^{2}$, Gorman $^{3}$ and Batenhorst et al. ${ }^{5}$ seem to indicate that tooth malposition is often associated with gingival recession. This is contrary to the findings of Pearson ${ }^{4}$. Also, Dorfman 6 found no strong correlation between labial tooth movement and loss of keratinized gingiva. Due to the conflicting results reached by previous authors, this study was undertaken to examine the effects of labial tooth movement on changes of the marginal periodontium. 


\section{MATERIAL AND METHODS}

\section{Animals}

Five adult female monkeys (Macaca nemistrina) were used as experimental subjects. The maxillary and mandibular central incisors were subjected to labial orthodontic movement and the canines served as untreated control teeth. The lateral incisors were not analyzed in an effort to separate the moved and unmoved teeth by a reasonable dimension.

\section{Oral Hygiene}

The teeth of each subject were initially thoroughly scaled and polished. Throughout orthodontic therapy each monkey received oral hygiene care according to two different methods. One arch was swabbed with chlorhexidine and flossed while the opposing arch was brushed with a soft toothbrush (Pycopay*) and toothpaste (Ultrabright**), and flossed (Fig. 1).

\section{Amalgam Marker}

An amalgam marker was placed on each facial surface of all anterior teeth. The marker was placed above the gingival margin but below the orthodontic brackets. All measurements were taken from the apical extent of the amalgam marker.

*Pycopay, Block Drug. Dorp., Jersey City, New Jersey 07302 **Ultrabright toothpaste, Colgate Palmolive Corp., New York New York. 
Parameters

Tooth movement (TM): The amount of labial tooth movement was calculated by comparing an initial measurement from the mesial fossa of the second bicuspid to the incisal edge of the central incisor with this same measurement after orthodontic tooth movement.

Gingival Margin (GM): Measurements were made from the apical extent of the amalgam marker to the gingival margin. The measurements were taken using dividers and were transferred to a record sheet by punching holes in the paper. The distance between the two points was later read with a comparator.

Mucogingival Junction (MGJ): After staining with Schiller's iodine solution ${ }^{7}$ measurements were made from the apical extent of the amalgam marker to the mucogingival junction. Dividers were used as above.

Width of Keratinized Gingiva (KG): This measurement was arrived at by subtracting the measurement of the gingival margin from the measurement of the mucogingival junction.

Connective Tissue Level (CTL): The level of the connective tissue attachment was determined by measuring from the apical extent of the amalgam marker to the most coronal extent of the connective tissue fibers subsequent to the careful elevation of a labial full thickness flap (Fig. 2). 
Toluidine blue was applied and used to delineate the level of the collagen fibers on the tooth surface $^{8}$ (Fig. 3). The pre-orthodontic exploratory surgery was performed on either right or left quadrants. The measurements for the connective tissue level on the teeth in the quadrants which received pre-orthodontic exploratory surgery served also as initial readings for contralateral teeth. Prior to surgery the distance from the incisal edge to the apical extent of the amalgam marker was measured with dividers. During surgery the measurement was made from the amalgam marker to the connective tissue level (Fig. 4). These two numbers were added and then used as initial measurements for the contralateral teeth. In this manner a measurement could be obtained for the teeth which were not operated surgically before the orthodontic tooth movement. The assumption was made that contralateral teeth would have similar anatomy.

Marginal Bone Level (MBL): The level of the marginal bone was also assessed during the pre-orthodontic exploratory surgery in a similar manner as for the connective tissue (Fig. 5). Fig. 1 describes the quadrants which received pre-orthodontic exploratory surgery.

The post-orthodontic surgery included all anterior teeth. Measurements were then taken on all centrals and cuspids. Dividers were used as above. 


\section{Orthodontics}

Edgewise orthodontic appliances were used to achieve tooth movement. Segment wires were positioned in each quadrant from first molar to lateral incisor including the second bicuspid and cuspid. The centrals were then bracketed to $16 \times 22$ elgiloy wire run through tubes located on each segment wire (Fig. 6). Activation of the appliance was achieved by the use of opencoil wire to provide approximately 50 grams of force in the labial direction (Fig. 7). The appliances were checked weekly to insure bodily movement, and to prevent extrusion. Bodily movement of the right and left central incisors in both arches was continuous until dehiscence in the alveolus was believed to have occurred. The presence of a dehiscence was evaluated by palpation and lateral cephalograms. Orthodontic forces were thus applied for a period of 13 weeks. A stabilization period of 3 weeks followed (Fig. 8). The experimental design is outlined in Fig. 9.

\section{Statistical Method}

To compare displaced central incisors and orthodontically untreated control cuspids for dependent variables (gingival margin, mucogingival junction, keratinized gingiva, connective tissue level and marginal bone level) a general analysis of variance program (BMD08V) was used. The variables of 
classification included orthodontic movement, animal and maxilla/mandible. Left/right was considered to be two duplications nested within animals. A fixed constant model was used on each variable of classification except for left/right.

A general linear hypothesis program (BMDX64) was used to test for the relationship between tooth movement and changes in the dependent variables. The program was adjusted for animal differences, maxillary/mandibular differences and interaction between maxillary and mandibular arches. Design variables were animal and maxilla/mandible. Tooth movement served as the covariate.

In order to determine if mechanical cleaning versus chlorhexidine treatment and initial exploratory surgery versus no surgery had any effect on the changes found in the dependent variables, the general linear hypothesis program (BMDX64) was again used. Animals, maxilla/mandible, mechanical cleaning/chlorhexidine, surgery/non-surgery, served as design variables. Interactions were not included in the model. 


\section{RESULTS}

The changes in pre- and post-experimental data including mean and standard deviations for all dependent variables can be found on Table 1 . Fig. 10 and Table 1 demonstrate the difference between the pre-experimental and post-experimental measurements for all displaced incisors and orthodontically untreated control cuspids. Upon comparison of displaced and control teeth there were significant differences in the distance from the amalgam marker to the gingival margin, the mucogingival junction, the connective tissue level and the marginal bone level. However, there was no difference in the width of the keratinized gingiva (Table 2).

The statistical data (Table 2) demonstrate a significant recession of the gingival margin $(p<0.001)$ in displaced incisors over orthodontically untreated control cuspids. Difference between the recession of the upper and lower teeth indicated an increased amount of recession associated with the lower arch $(p<0.05)$. A similar difference was found in the distance from the amalgam marker to the mucogingival junction, except that in this respect the difference between displaced versus control teeth was only significant to the 0.01 level.

The analysis of the difference between displaced and orthodontically untreated control teeth in relation to the 
connective tissue level found a loss of connective tissue attachment significant to the 0.001 level. Significant differences were found between the reactions of various animals $(p<0.01)$ and the interaction between animals and orthodontic movement $(p<0.05)$. The change in the height of the facial alveolar bone was significantly different to the 0.001 level when comparing displaced versus control teeth. Significant differences were also found between the changes observed in different animals, in maxillary and mandibular arches, and in interactions of these two variables $(p<0.01)$. The amount of recession of the gingival margin and changes in the distance from the amalgam marker to the mucogingival junction, the connective tissue level and the marginal bone level were all found to be not statistically significantly related to the amount of tooth movement.*

The displaced teeth which were brushed and flossed had no changes which were different from the changes in those teeth which were swabbed with chlorhexidine.*

The teeth which received pre-experimental exploratory surgery had the same changes in the measurements for the gingival margin, mucogingival junction, connective tissue level and marginal bone level as had the contralateral unsurgerized teeth.*

*Statistical method and data available upon request. 


\section{DISCUSSION}

This study was designed to analyze the relationship between labial tooth movement and changes of the marginal periodontium.

The selection of centrals as orthodontically displaced teeth and canines as untreated controls was necessitated by a number of factors. The main reason was the need to design an appliance in which displaced and control teeth were in the same arch but separated by at least one tooth. The appliance had to be easily adjustable but have the ability to withstand the abuse of very dexterous monkeys. The use of centrals as displaced teeth allowed the construction of a heavy appliance which could apply bilateral forces and also have the benefits of using cuspids, which are not easily displaced, as control teeth.

The measurement of the connective tissue level was achieved by the use of toluidine blue stain. This stain was used by Waerhaug ${ }^{8}$ to locate the connective tissue level on extracted teeth. Toluidine blue worked well for our in vivo purpose.

The results demonstrate that labial tooth movement results in loss of marginal bone and connective tissue attachment as well as in gingival recession. 
A major factor which differentiates this report from the clinical situation is the duration of tooth movement and retention periods. Given more time, areas of more extensive recession may have developed. The amount of gingival recession found in this study was statistically significant. However, areas with extensive gingival recession similar to what can be observed in man were not seen.

The gingival changes observed as a result of labial displacement during this study correlated well with previous reports associating tooth position and recession. ${ }^{1-3}, 5$

The width of the keratinized gingiva did in the present study not change significantly. On the other hand, an increase in the distance from the amalgam marker to the MGJ was observed. According to studies on human, an increase in the distance from the cemento-enamel junction to the MGJ is indicative of an eruptive movement of the tooth. ${ }^{9-11}$ The threedimensional movement of anatomical landmarks in the present experiment makes the evaluation of the measurements more complicated but the possibility remains that, despite precaution, the displaced teeth slightly erupted concurrently with the labial movement. The effect of the recession on the width of the keratinized gingiva was thus compensated for by the eruption of the tooth.

The recent publication by Dorfman ${ }^{6}$ of a post-orthodontic 
study in humans indicates no relationship between changes in the width of keratinized gingiva and the amount of facial tooth movement. This finding is in agreement with the results of the present study.

The changes in the level of the alveolar bone demonstrate that it is possible to move a tooth out of its alveolar housing. The data collected for this measurement did not reflect the total degree of bone lost facial to the displaced teeth. Initially no dehiscences or fenestrations were found. Post therapy measurements were made to the first encountered bone on the facial surfaces. Often, apical to this bone, fenestrations in the alveolus were found to the root apex.

The mechanism by which recession occurred in this study may be associated with tension created in the gingivagenerated by orthodontic forces. As tooth movement occurred the gingiva located facially to the displaced teeth seemed to become thinned. The distofacial surfaces of the moved teeth showed the most obvious signs of loss of connective tissue attachment as evidenced by exposed cementum (Fig. 8). Throughout the study, in spite of excellent oral hygiene, signs of gingival inflammation persisted at these surfaces. It appears that the alveolar process provides a natural housing which is covered by keratinized gingiva. If a țooth 
is moved outside the alveolar process it may also move out of its gingival coverage.

Thus, indirect evidence from previous cross-sectional studies in humans plus data from the present experimental study and the study by Batenhorst et al. ${ }^{5}$ in monkeys provide evidence that tooth malposition plays an important role in the process of gingival recession. In an effort to preserve the supporting structures of the dentition, the relationship between facial displacement and recession should be considered. 
TABLE 1. Changes in dependent variables during 16 weeks of orthodontic therapy, comprising 13 weeks of labial movement of central incisors and a subsequent 3 week stabilization period. The abbreviations are for amount of labial movement (TM), change in width of keratinized gingiva (KG), and change in distance from amalgam marker to gingival margin (GM), mucogingival junction (MGJ), level of connective tissue (CTL) and marginal bone level (MBL). All measurements are in millimeters.

\begin{tabular}{|c|c|c|c|c|c|c|c|c|c|c|c|c|c|}
\hline \multirow[t]{2}{*}{ ANIIIAL } & \multicolumn{7}{|c|}{ DISPLACED INCISORS } & \multicolumn{6}{|c|}{ CONTROL CUSPIDS } \\
\hline & ТООТн & TM & GM: & MGJ & KG & CTL & MBL & тоОтн & GM & MGJ & KG & CTL & MBL \\
\hline 1 & $\begin{array}{r}8 \\
9 \\
24 \\
25\end{array}$ & $\begin{array}{l}2.0 \\
2.5 \\
2.0 \\
3.0\end{array}$ & $\begin{array}{l}0.3 \\
0.5 \\
0.6 \\
0.9\end{array}$ & $\begin{array}{l}0.8 \\
0.4 \\
0.6 \\
0.5\end{array}$ & $\begin{array}{r}0.5 \\
-0.1 \\
0.0 \\
-0.4\end{array}$ & $\begin{array}{l}0.2 \\
0.5 \\
0.7 \\
0.8\end{array}$ & $\begin{array}{l}8.1 \\
7.9 \\
7.2 \\
3.1\end{array}$ & $\begin{array}{r}6 \\
11 \\
22 \\
27\end{array}$ & $\begin{array}{r}-0.2 \\
-0.2 \\
0.0 \\
0.3\end{array}$ & $\begin{array}{r}-0.3 \\
-0.4 \\
0.2 \\
0.8\end{array}$ & $\begin{array}{r}-0.1 \\
-0.2 \\
0.2 \\
0.5\end{array}$ & $\begin{array}{r}-1.5 \\
-0.1 \\
0.9 \\
1.2\end{array}$ & $\begin{array}{l}0.3 \\
0.8 \\
1.3 \\
6.4\end{array}$ \\
\hline 2 & $\begin{array}{r}8 \\
9 \\
24 \\
25\end{array}$ & $\begin{array}{l}4.0 \\
4.0 \\
3.0 \\
4.0\end{array}$ & $\begin{array}{l}1.3 \\
1.5 \\
1.6 \\
1.4\end{array}$ & $\begin{array}{l}2.0 \\
1.4 \\
1.6 \\
1.4\end{array}$ & $\begin{array}{r}0.7 \\
-0.1 \\
0.0 \\
0.0\end{array}$ & $\begin{array}{l}3.7 \\
3.0 \\
4.1 \\
3.7\end{array}$ & $\begin{array}{l}0.1 \\
0.5 \\
2.7 \\
2.8\end{array}$ & $\begin{array}{r}6 \\
11 \\
22 \\
27\end{array}$ & $\begin{array}{l}0.3 \\
0.2 \\
0.1 \\
0.2\end{array}$ & $\begin{array}{l}0.3 \\
0.2 \\
0.0 \\
0.2\end{array}$ & $\begin{array}{r}0.0 \\
-0.1 \\
0.3 \\
0.0\end{array}$ & $\begin{array}{l}2.3 \\
0.8 \\
2.2 \\
1.3\end{array}$ & $\begin{array}{r}1.3 \\
-1.1 \\
3.7 \\
3.0\end{array}$ \\
\hline 3 & $\begin{array}{r}8 \\
9 \\
24 \\
25\end{array}$ & $\begin{array}{l}2.0 \\
2.0 \\
3.5 \\
3.5\end{array}$ & $\begin{array}{l}1.1 \\
0.6 \\
0.8 \\
1.3\end{array}$ & $\begin{array}{l}1.1 \\
0.3 \\
0.9 \\
1.8\end{array}$ & $\begin{array}{r}0.0 \\
-0.3 \\
0.1 \\
0.5\end{array}$ & $\begin{array}{l}1.5 \\
1.6 \\
1.6 \\
1.3\end{array}$ & $\begin{array}{l}7.5 \\
6.3 \\
6.2 \\
5.0\end{array}$ & $\begin{array}{r}6 \\
11 \\
22 \\
27\end{array}$ & $\begin{array}{l}0.1 \\
0.2 \\
0.3 \\
0.7\end{array}$ & $\begin{array}{l}0.0 \\
0.2 \\
0.7 \\
0.6\end{array}$ & $\begin{array}{r}-0.1 \\
0.0 \\
0.4 \\
-0.1\end{array}$ & $\begin{array}{r}-1.5 \\
0.0 \\
0.0 \\
-1.7\end{array}$ & $\begin{array}{l}1.4 \\
1.2 \\
0.5 \\
1.2\end{array}$ \\
\hline 4 & $\begin{array}{r}8 \\
9 \\
24 \\
25\end{array}$ & $\begin{array}{l}2.5 \\
2.0 \\
4.0 \\
3.5\end{array}$ & $\begin{array}{l}0.6 \\
1.0 \\
1.5 \\
1.3\end{array}$ & $\begin{array}{l}0.1 \\
1.1 \\
0.9 \\
0.0\end{array}$ & $\begin{array}{l}-0.5 \\
-0.1 \\
-0.6 \\
-1.3\end{array}$ & $\begin{array}{l}1.9 \\
1.5 \\
1.6 \\
1.3\end{array}$ & $\begin{array}{l}1.0 \\
0.6 \\
7.8 \\
7.4\end{array}$ & $\begin{array}{r}6 \\
11 \\
22 \\
27\end{array}$ & $\begin{array}{l}0.5 \\
0.0 \\
0.1 \\
0.8\end{array}$ & $\begin{array}{l}0.4 \\
0.2 \\
0.3 \\
0.2\end{array}$ & $\begin{array}{r}-0.1 \\
0.2 \\
0.3 \\
0.6\end{array}$ & $\begin{array}{l}1.4 \\
1.4 \\
0.5 \\
1.0\end{array}$ & $\begin{array}{l}2.3 \\
0.3 \\
1.7 \\
3.1\end{array}$ \\
\hline 5 & $\begin{array}{r}8 \\
9 \\
24 \\
25\end{array}$ & $\begin{array}{l}2.5 \\
3.5 \\
4.0 \\
3.5\end{array}$ & $\begin{array}{l}1.2 \\
0.8 \\
0.6 \\
1.2\end{array}$ & $\begin{array}{l}1.3 \\
1.0 \\
1.8 \\
1.4\end{array}$ & $\begin{array}{l}0.1 \\
0.2 \\
1.2 \\
0.3\end{array}$ & $\begin{array}{l}1.9 \\
1.9 \\
2.4 \\
2.2\end{array}$ & $\begin{array}{r}10.2 \\
6.3 \\
9.1 \\
7.6\end{array}$ & $\begin{array}{r}6 \\
11 \\
22 \\
27\end{array}$ & $\begin{array}{r}0.3 \\
0.1 \\
-0.2 \\
0.5\end{array}$ & $\begin{array}{l}0.2 \\
0.3 \\
0.1 \\
0.2\end{array}$ & $\begin{array}{r}-0.1 \\
0.2 \\
0.3 \\
-0.1\end{array}$ & $\begin{array}{r}2.4 \\
1.4 \\
0.7 \\
-0.1\end{array}$ & $\begin{array}{r}-0.2 \\
1.2 \\
0.5 \\
-0.1\end{array}$ \\
\hline $\begin{array}{l}\text { MEAN } \\
\text { STANDARD } \\
\text { DEVIATION }\end{array}$ & & $\begin{array}{l}3.05 \\
0.8\end{array}$ & $\begin{array}{l}1.01 \\
0.4\end{array}$ & $\begin{array}{l}1.02 \\
0.6\end{array}$ & $\begin{array}{l}0.01 \\
0.5\end{array}$ & $\begin{array}{l}1.93 \\
1.1\end{array}$ & $\begin{array}{l}5.48 \\
3.1\end{array}$ & & $\begin{array}{l}0.20 \\
0.3\end{array}$ & $\begin{array}{l}0.23 \\
0.3\end{array}$ & $\begin{array}{l}0.10 \\
0.2\end{array}$ & $\begin{array}{l}0.89 \\
0.3\end{array}$ & $\begin{array}{l}1.52 \\
1.0\end{array}$ \\
\hline
\end{tabular}


TABLF: 2. Lnalysis of variance for dependent variables - orthodontically displaced incisors versus control cuspids. See table 1 for abbreviations.

\begin{tabular}{|c|c|c|c|c|c|c|}
\hline VARIABLE & SOURCE & $\begin{array}{l}\text { SUM OF } \\
\text { SQUARES }\end{array}$ & $\begin{array}{l}\text { MEAN } \\
\text { SQUARES }\end{array}$ & $\begin{array}{l}\text { DEGREE OF } \\
\text { FREEDOM }\end{array}$ & $\mathrm{F}$ & $\mathrm{P}$ \\
\hline \multirow[t]{6}{*}{$G M$} & MEAN & 14.52 & 14.52 & 1 & 99.62 & .001 \\
\hline & I (orth.movement) & 6.480 & 6.480 & 1 & 60.70 & .001 \\
\hline & $\mathrm{J}($ animal) & 1.353 & .3383 & 4 & 2.32 & NS \\
\hline & K (Upper/lower) & .3422 & $.3422 \backslash$ & 1 & 8.83 & .05 \\
\hline & $\mathrm{IJ}$ & .5985 & .1496 & 4 & 1.40 & NS \\
\hline & JK & .3864 & .9662 & 4 & 2.49 & VS \\
\hline \multirow[t]{6}{*}{$\mathrm{MGJ}$} & MEAN & 15.62 & 15.62 & 1 & 96.74 & .001 \\
\hline & I (orth.movement) & 6.240 & 6.240 & 1 & 20.22 & .01 \\
\hline & $\mathrm{J}$ (animal) & 2.042 & .5106 & 4 & 3.16 & NS \\
\hline & K (Upper/lower) & .3999 & 3999 & 1 & 10.38 & .05 \\
\hline & IJ & 1.771 & .4428 & 4 & 2.14 & .vS \\
\hline & $\mathrm{JK}$ & .7324 & .1831 & 4 & 4.75 &.$v S$ \\
\hline \multirow[t]{6}{*}{ KG } & MEAN & .1322 & .1322 & 1 & 1.09 & NS \\
\hline & I (orth.movement) & .9024 & .9024 & 1 & 0.89 & NS \\
\hline & $\mathrm{J}$ (animal) & .8314 & .2078 & 4 & 1.72 & NS \\
\hline & K (Upper/lower) & .1102 & .1102 & 1 & 1.43 & NS \\
\hline & IJ & 1.763 & .4408 & 4 & 4.37 & NS \\
\hline & JK & .3534 & .8837 & 4 & 1.15 & NS \\
\hline \multirow[t]{6}{*}{ CTL } & MEAN & 62.49 & 62.49 & 1 & 158.02 & .001 \\
\hline & I (orth.movement) & 15.37 & 15.37 & 1 & 67.89 & .001 \\
\hline & $\mathrm{J}$ (animal) & 29.56 & 7.391 & 4 & 18.68 & .01 \\
\hline & K (Upper/lower) & .4899 & .4899 & 1 & 0.09 & NS \\
\hline & $\mathrm{IJ}$ & 5.866 & 1.466 & 4 & 6.47 & .05 \\
\hline & $\mathrm{JK}$ & 3.908 & .9771 & 4 & 1.87 & NS \\
\hline \multirow[t]{8}{*}{$\mathrm{MBL}$} & MEAN & 467.1 & 467.1 & 1 & & \\
\hline & I (orth.movement) & 156.4 & 156.4 & 1 & 60.26 & .001 \\
\hline & $J($ animal) & 42.47 & 10.61 & 4 & 28.63 & .01 \\
\hline & K (Upper/lower) & 14.04 & 14.04 & 1 & 18.21 & .01 \\
\hline & IJ & 76.95 & 19.23 & 4 & 7.41 & .05 \\
\hline & JK & 35.14 & 8.785 & 4. & 11.39 & .01 \\
\hline & .05 & .01 & .001 & & & \\
\hline & $\begin{array}{l}F(1,5) \\
1:(4,5) \\
F(4,4)\end{array}$ & $\begin{array}{l}16.3 \\
11.4 \\
21.2\end{array}$ & & & & \\
\hline
\end{tabular}




\section{REFERENCES}

1. Parfitt, G. J. and Mjor, I. A.: A clinical evaluation of local gingival recession in children. J Dentistry for Children $31: 257,1964$.

2. Trott, J. R. and Love, B.: An analysis of localized gingival recession in 766 Winnipeg high school students. Dent Pract and Dent Record 16:209, 1966.

3. Gorman, W. J.: Prevalence and etiology of gingival recession. J Periodontol 38:316, 1967.

4. Pearson, L. E.: Gingival height of lower central incisors orthodontically treated and untreated. Angle Orthodon 38:337, 1968.

5. Batenhorst, K. R., Bowers, G. M. and Williams, Jr., J. E.: Tissue changes resulting from facial tipping and extrusion of incisors in monkeys. J Periodontol 45:660, 1974 .

6. Dorfman, H. S.: Mucogingival changes resulting from mandibular incisor tooth movement. Amer J Orthodon 73:286, 1978 .

7. Lang, N. P. and Loe, H.: The relationship between the width of keratinized gingiva and gingival health. J Periodontol 43:623, 1972 .

8. Waerhaug, J.: Subgingival plaque and loss of attachment in periodontosis as evaluated on extracted teeth. J Periodontol $48: 125,1977$.

9. Ainamo, J. and Talari, A.: The increase with age of the width of attached gingiva. J Periodont Res 13:189, 1978 .

10. Ainamo, A.: Influence of age on the location of the maxillary mucogingival junction. J Periodont Res 13:189, 1978.

11. Ainamo, A. and Ainamo, J.: The width of attached gingiva on supra-erupted teeth. J Periodont Res 13:194, 1978 . 


\section{LEGENDS}

FIGURE 1. Diagram distribution of the variables oral hygiene and pre-orthodontic exploratory surgery on animals number $1,3,5$. The remaining animals $(2,4)$ received identical treatment but in opposite quadrants and arches.

FIGURE 2. Pre-orthodontic exploratory surgery.

FIGURE 3. Application of toluidine blue. The stained areas include plaque and collagen fibers. The unstained area between collagen fibers and plaque indicates previous epithelial attachment.

FIGURE 4. Measurement of the level of connective tissue attachment.

FIGURE 5. Measurement of the level of the marginal bone.

FIGURE 6. Orthodontic appliance used to create labial displacement of the central incisors.

FIGURE 7. Tooth and gingival relationships prior to orthodontic therapy.

FIGURE 8. After orthodontic therapy.

FIGURE 9. Experimental design.

FIGURE 10. Changes in dependent variables (parameters) for displaced versus control teeth - mean and standard deviations in millimeters. Positive values indicate an increase in the distance from the amalgam marker to the parameter being measured. 


\section{RIGHT QUADRANT LEFT QUADRANT}

\begin{tabular}{|c|c|c|}
\hline MAXILLA & $\begin{array}{c}\text { chlorhexidine } \\
\text { swab }\end{array}$ & $\begin{array}{c}\text { exploratory } \\
\text { surgery } \\
\text { chlorhexidine } \\
\text { swab }\end{array}$ \\
\hline MANDIBLE & $\begin{array}{l}\text { mechanical } \\
\text { cleaning }\end{array}$ & $\begin{array}{c}\text { exploratory } \\
\text { surgery } \\
\text { mechanical } \\
\text { cleaning }\end{array}$ \\
\hline
\end{tabular}

Fig. 1. Steiner et al. 


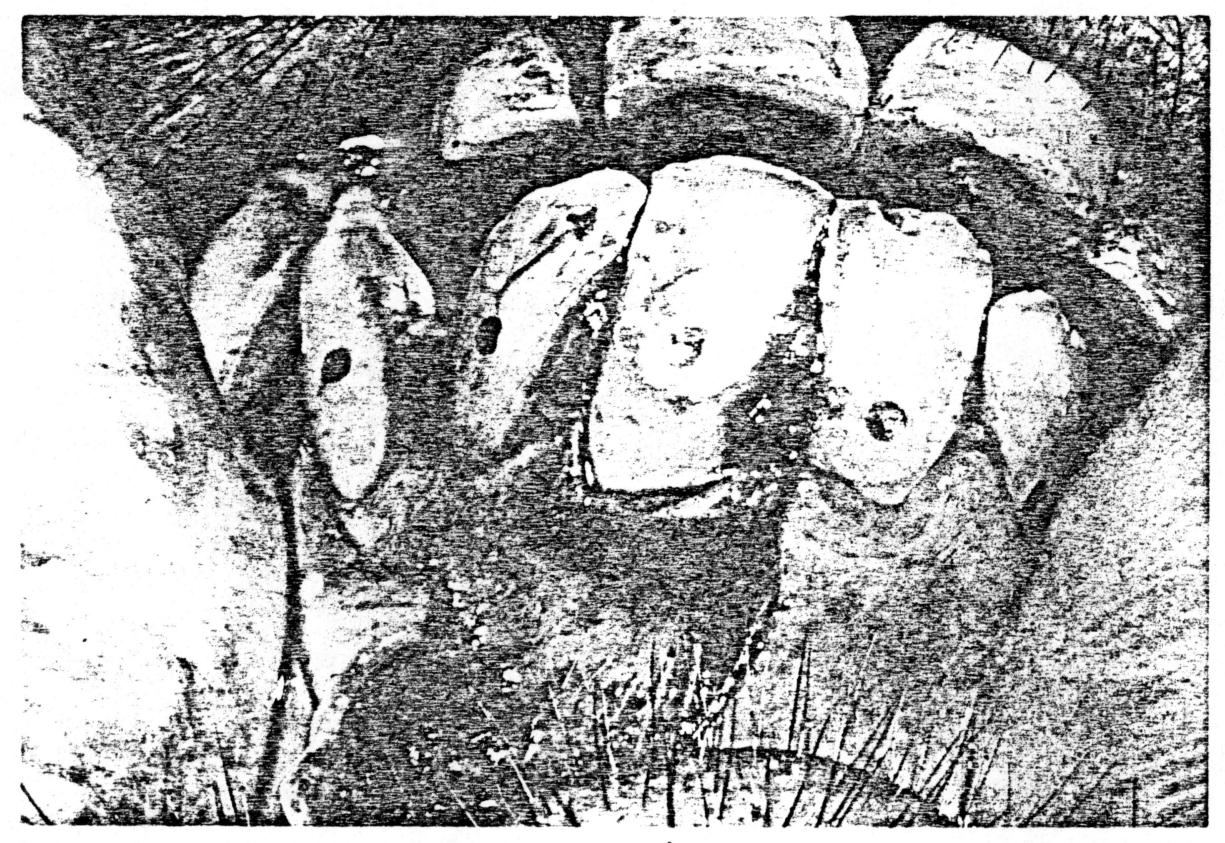

Fig. 2. Steiner et al. 


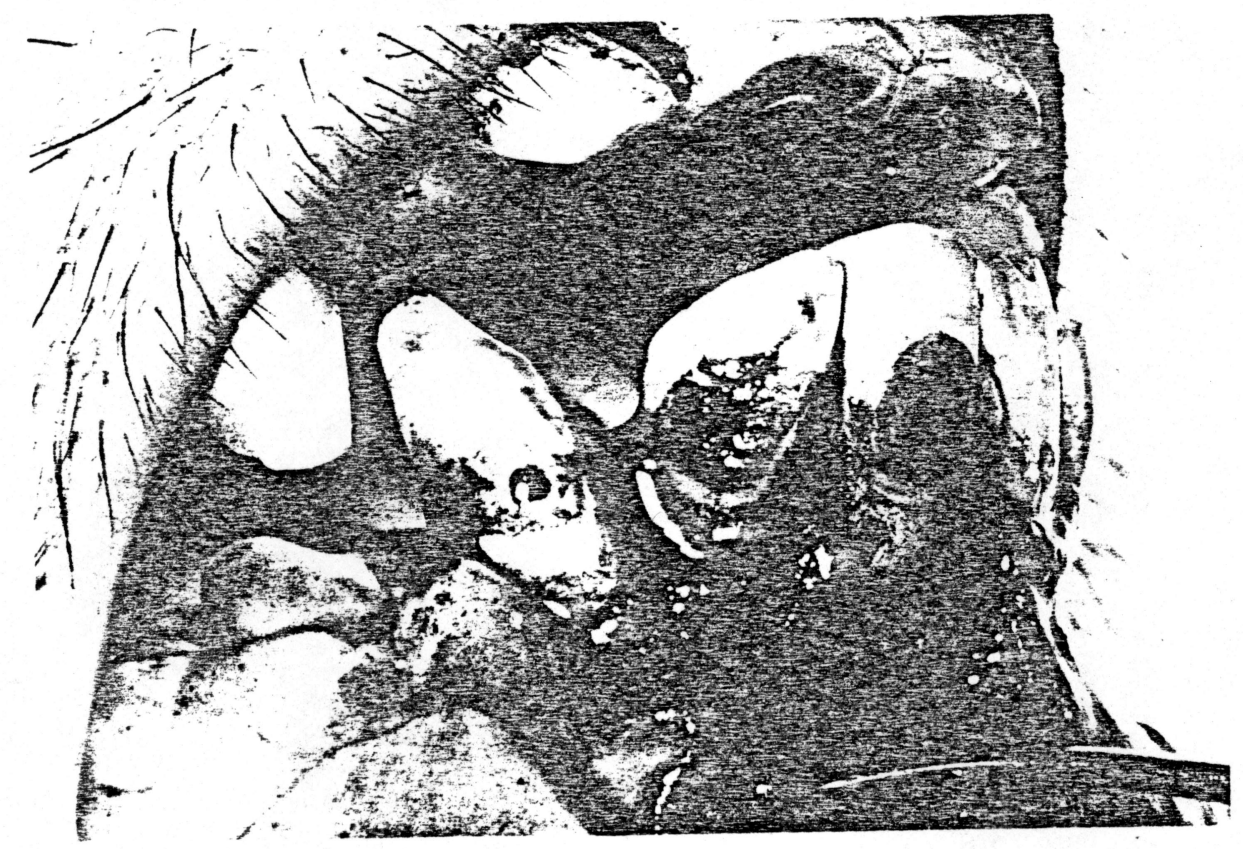

Fig. 3. Steiner et al. 


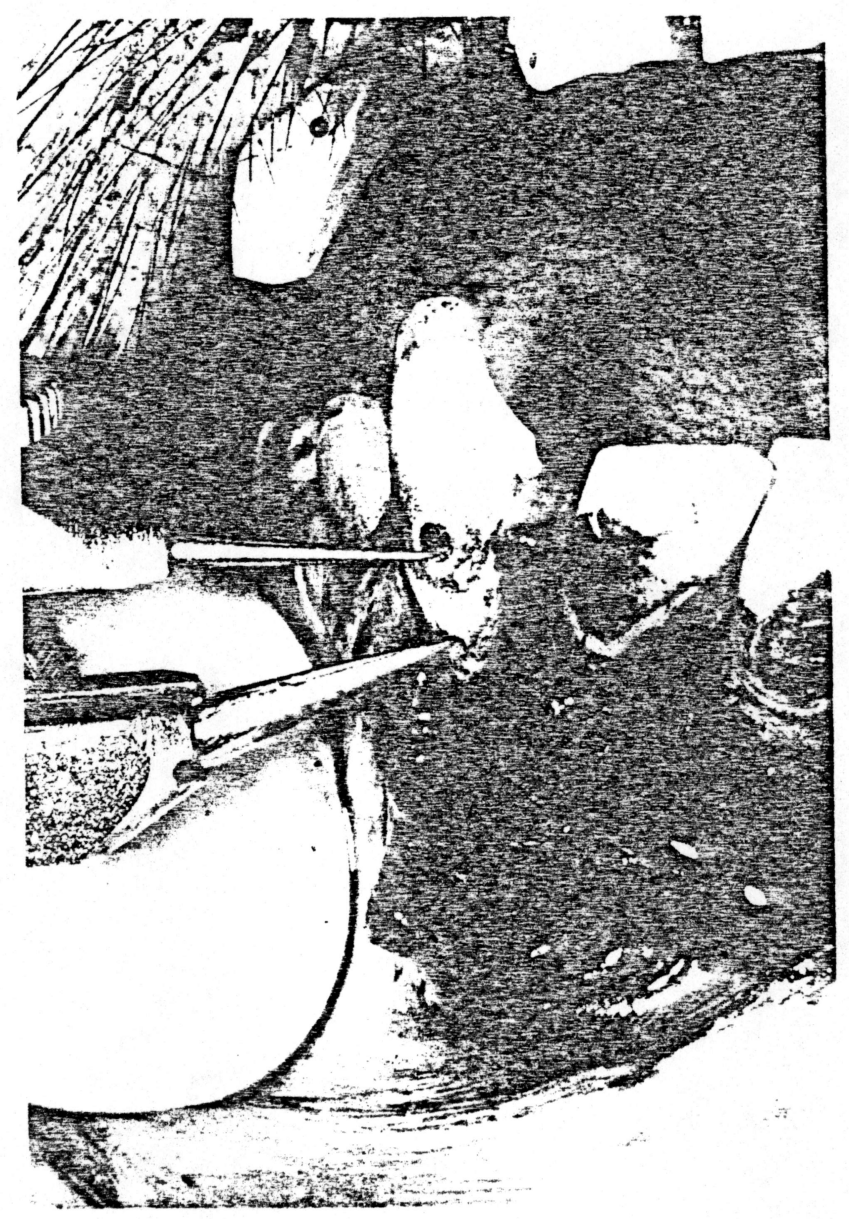

Fig. 4. Steiner et al. 


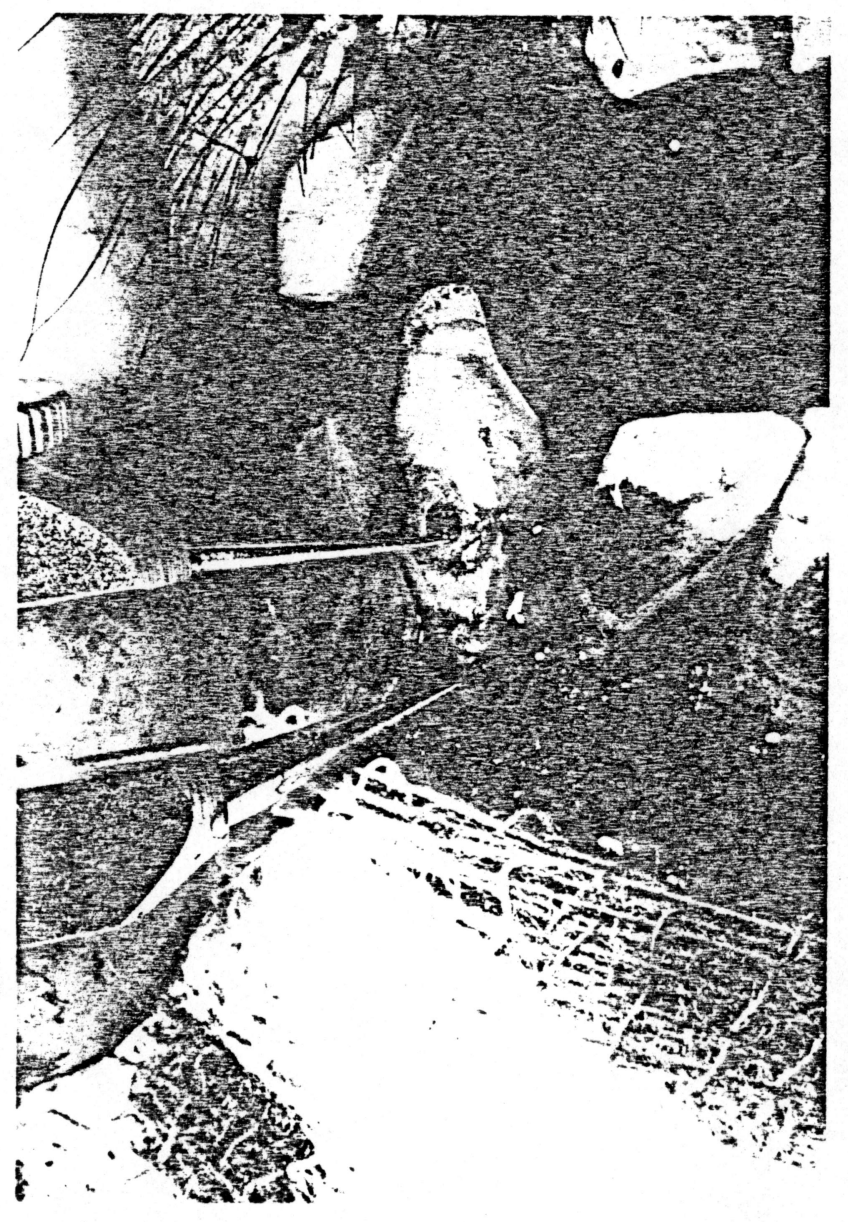

Fig. 5. Steiner et al. 


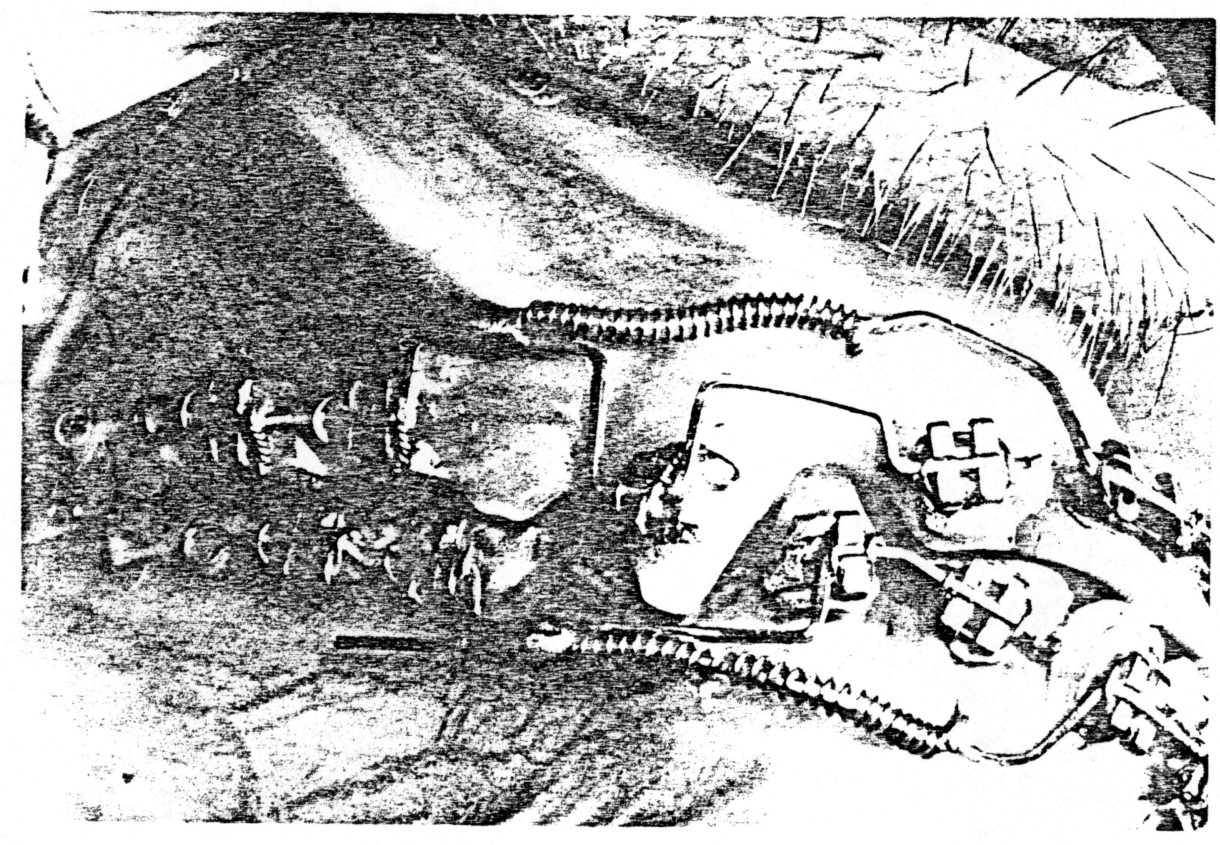

Fig. 6. Steiner et al. 


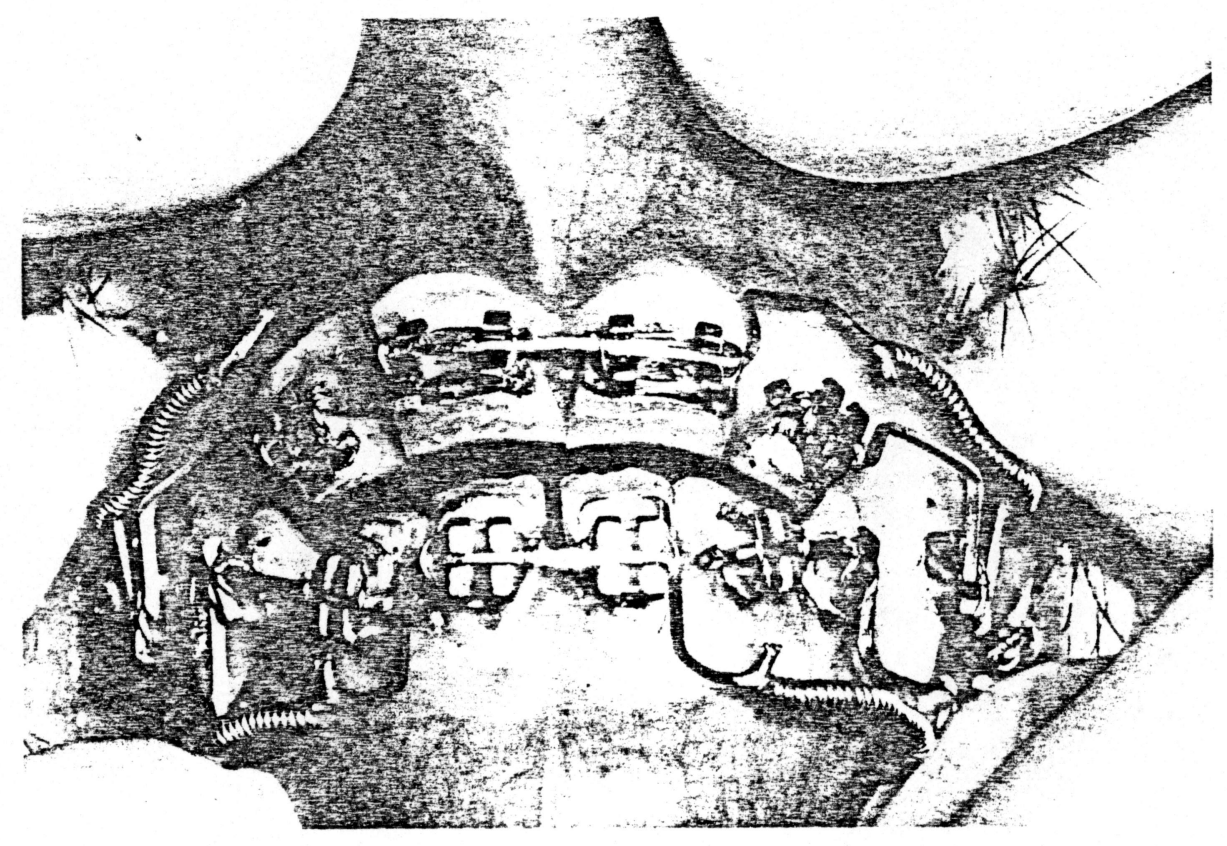

Fig. 7. Steiner et al. 


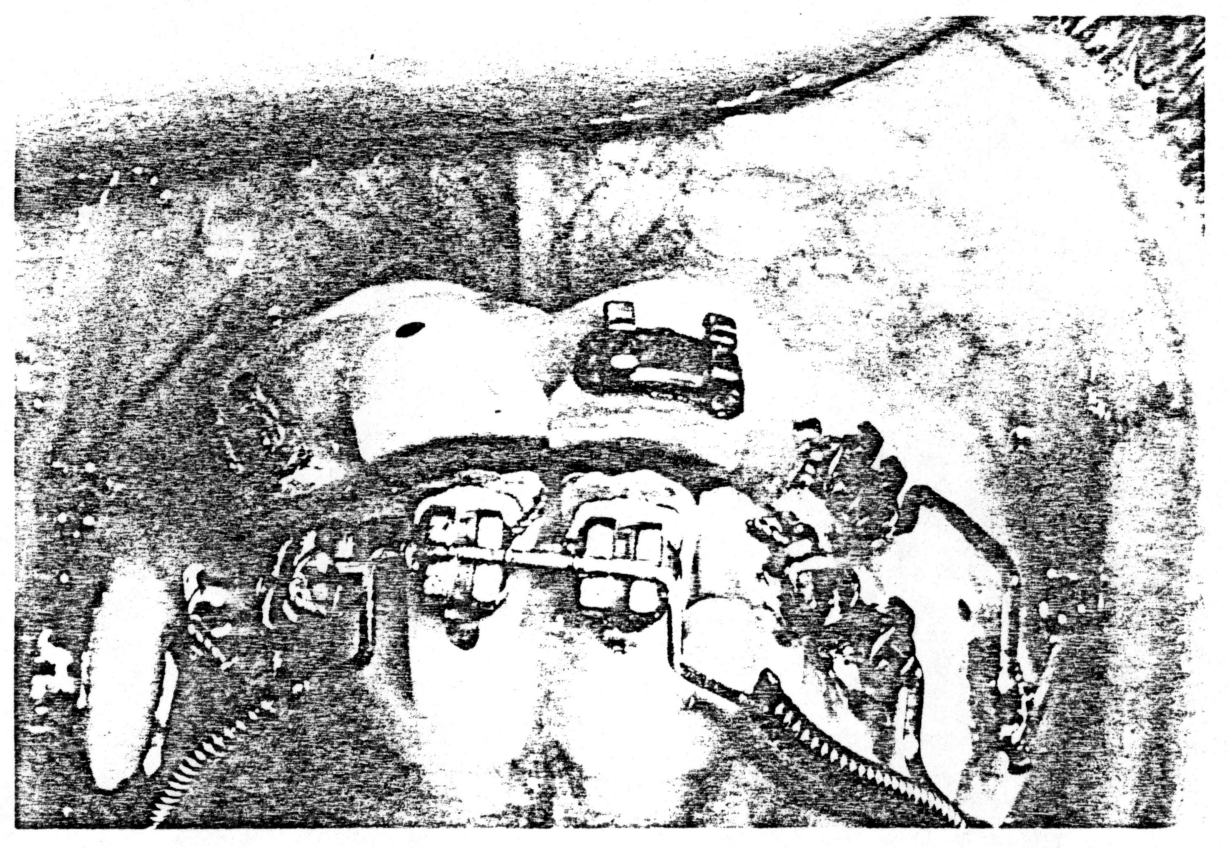

Fig. 8. Steiner et al. 
EXPERIMENTAL DESIGN

\section{Procedures}

Surgery on right quadrants of monkeys

1.3 and 5 . Surgery on

left quadrants of

monkeys 2 and 4

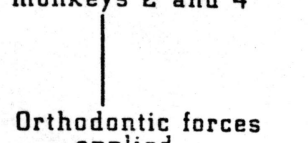

Orthodontic forces applied

$\left.\right|_{\text {Stabilization }}$ anterior teeth

\section{Measurements}

8 weeks

Marker to marginal bone level and con nective tissue level

(

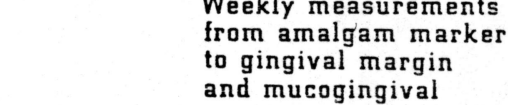

o gingival margin junction

13 weeks

3 weeks

Final measurements of gingival margin,

mucogingival junction

connective tissue level

and marginal bone level

Fig. 9. Steiner et al. 
Figure 10: Changes in dependent variables (parameters) for treated versus untreated teeth - mean and standard deviations in millimeters. Positive values indicate an increase in the distance from the amalgam marker to the parameter being measured.

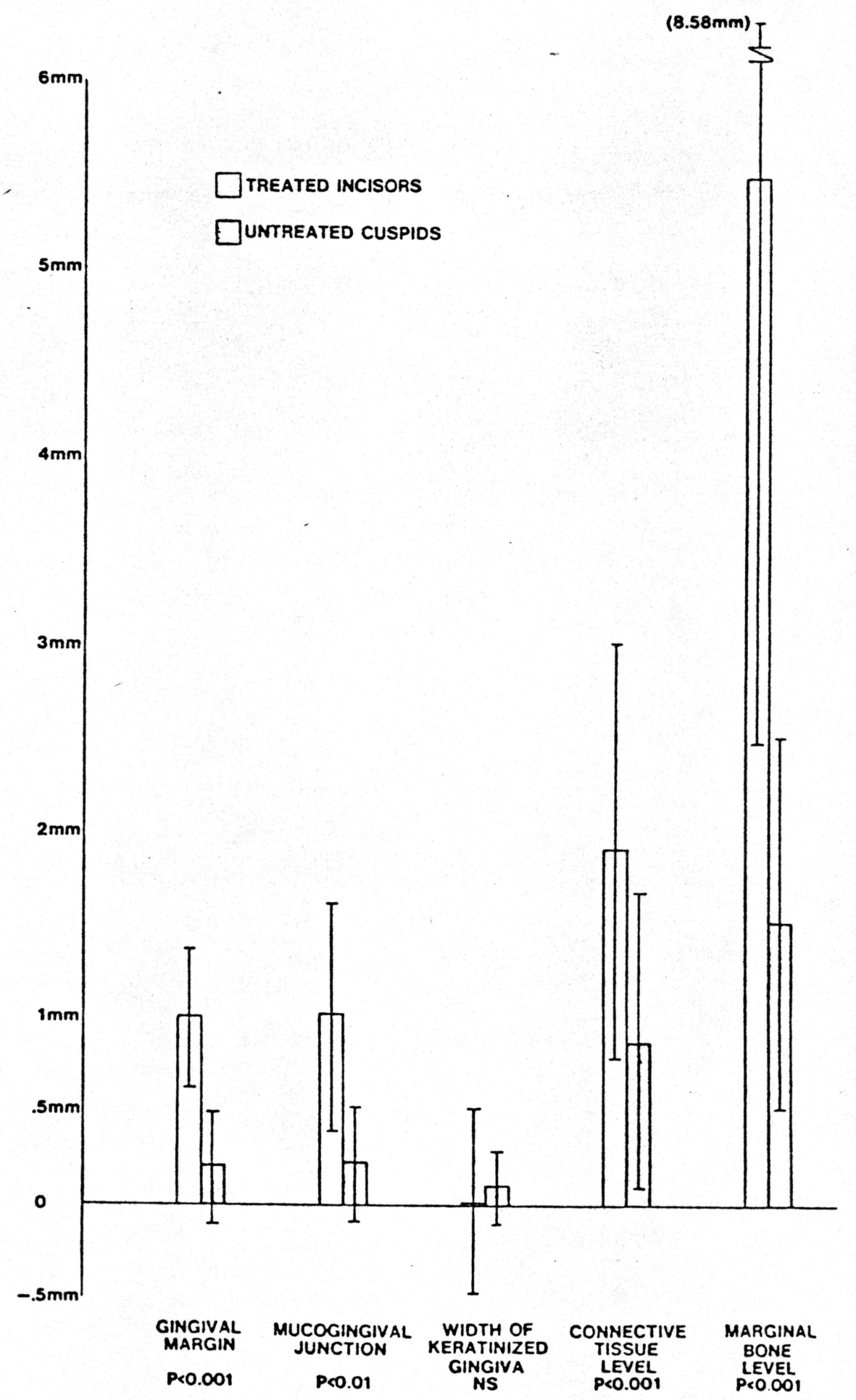

